\title{
Genetic and Molecular Basis of Botrydial Biosynthesis: Connecting Cytochrome P450-Encoding Genes to Biosynthetic Intermediates
}

Javier Moraga, ${ }^{\dagger}$ Bérengère Dalmais,,${ }^{\ddagger}$ Inmaculada Izquierdo-Bueno, ${ }^{\dagger}$ Josefina Aleu, ${ }^{\dagger}$ James R. Hanson, ${ }^{\S}$ Rosario Hernández-Galán, ${ }^{\dagger}$ Muriel Viaud, ${ }^{\ddagger}$ and Isidro G. Collado, ${ }^{\dagger}$

${ }^{\dagger}$ Departamento de Química Orgánica, Facultad de Ciencias, Universidad de Cádiz, Puerto Real, 11510 Cádiz, Spain

${ }^{\ddagger}$ UMR BIOGER, INRA, AgroParisTech, Université Paris-Saclay, 78850 Thiverval-Grignon, France

${ }^{\S}$ Department of Organic Chemistry, University of Sussex, Brighton, Sussex BN1 9QJ, United Kingdom

\section{Supporting Information}

ABSTRACT: Over two hundred species of plants can be infected by the phytopathogenic fungus Botrytis cinerea under a range of different environmental conditions. In response to these, the fungus produces unique terpenoid and polyketide metabolites. Parts of the plants may be killed by the phytotoxin botrydial, enabling the fungus to feed on the dead cells. In this paper, we describe the genetic and molecular basis of botrydial biosynthesis and the function of the five genes of the genome of $B$. cinerea that together constitute the botrydial biosynthetic gene cluster. Genes BcBOT3 and BcBOT4, encoding two cytochrome $\mathrm{P} 450$ monooxygenases, were inactivated by homologous recombination and were shown to catalyze regio- and stereospecific hydroxylations at the carbons $\mathrm{C}-10$ and C- 4 , respectively, of the presilphiperfolan- $8 \beta$-ol skeleton. The null mutants, bcbot $3 \Delta$ and $b c b o t 4 \Delta$, accumulated key intermediates in the botrydial biosynthesis enabling the complete genetic and molecular basis of the botrydial biosynthetic pathway to be established. Furthermore, the bcbot $4 \Delta$ mutant overproduced a significant number of polyketides, which included, in addition to known botcinins, botrylactones and cinbotolide A, two new botrylactones and two new cinbotolides, cinbotolides $\mathrm{B}$ and $\mathrm{C}$.

F ungal secondary metabolites have a wide impact on human health, medicine, and agriculture. While many secondary metabolites including antibiotics, immunosuppressants, and phytohormones are beneficial, other such as phytotoxins and mycotoxins are harmful to plants, humans, and animals. ${ }^{1}$ In order to manage or modify the biosynthesis of secondary metabolites, we need to identify the location of the genes encoding the relevant biosynthetic enzymes. The genes that encode the biosynthesis of structurally related secondary metabolites are often clustered. The horizontal gene transfer $(\mathrm{HGT})^{2}$ between distant fungi may be facilitated by such clustering, conferring an evolutionary advantage. ${ }^{3-6}$

The Ascomycete Botrytis cinerea is the cause of "gray mold" disease of a wide range of dicoyledons under a variety of environmental conditions in which its secondary metabolites (SM) confer a selective advantage. $B$. cinerea has the characteristics of a necrotroph in which the infection may be mediated by the production of phytotoxins and reactive oxygen species, as well as by inducing an oxidative burst in the plant. ${ }^{7,8}$ A number of unique terpenoids and polyketides have been obtained from the mycelium. These include two groups of nonspecific phytotoxins. The first are the sesquiterpenoid botryanes, ${ }^{9}$ botrydial (1) and dihydrobotrydial (2). The second are the polyketide lactones, botrylactone $(3)^{10}$ together with botcinic (4) and botcineric acid (5), ${ }^{11}$ and their cyclic relatives, the botcinins $(6,7) \cdot{ }^{12}$ Cinbotolide $(8)$ is a new polyketide that has been reported and contains a carbon chain that possesses structural features and a stereochemistry reminiscent of the botcinins and botrylactone (Figure 1$)^{13}$

Botrydial (1) is the major phytotoxin ${ }^{14,15}$ of B. cinerea, and it has been shown to reproduce the symptoms of the infection. ${ }^{16,17}$ Spectroscopic, chemical, and X-ray methods ${ }^{18-20}$ were used to establish the irregular sesquiterpenoid structures of these botryane metabolites. Their biosynthesis via farnesyl diphosphate (FPP, Figure 2) has been elucidated. ${ }^{21-24}$

The genome of $B$. cinerea has been sequenced leading to the identification of the genes that are responsible for the synthesis of its secondary metabolites. Forty-four genes that encode key enzymes (KE) that are responsible for the committed biosynthetic steps were identified from sequences in two strains, BO5.10 (B cero five.ten) and T4. ${ }^{25,26}$ Typical of the secondary metabolism of filamentous fungi, the majority of the genes that encode these key enzymes are part of biosynthetic

Received: July 6, 2016

Accepted: August 16, 2016

Published: August 16, 2016 


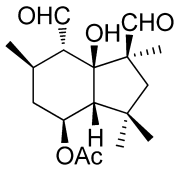

1 Botrydial

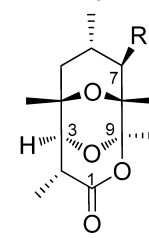

$3 \mathrm{R}=\mathrm{OH}$ Botrylactone<smiles>[R2]C1[C@H](C)O[C@@]2([C@@H](C)OC(=O)[C@H](C)[C@H]2O)[C@@H]1O</smiles>

$6 \mathrm{R}=\mathrm{Ac}, \mathrm{n}=3 ;$ Botcinin $\mathrm{A}$ 7 R=Ac, $n=5$; Botcinin $B$

Figure 1. Some metabolites isolated from Botrytis cinerea.

gene clusters. Among them, the botrydial biosynthetic gene cluster has been identified (Figure 3). ${ }^{27,28}$ The cluster, which consists of five genes (BcBOT1 to BcBOT5) (for Botrytis cinerea

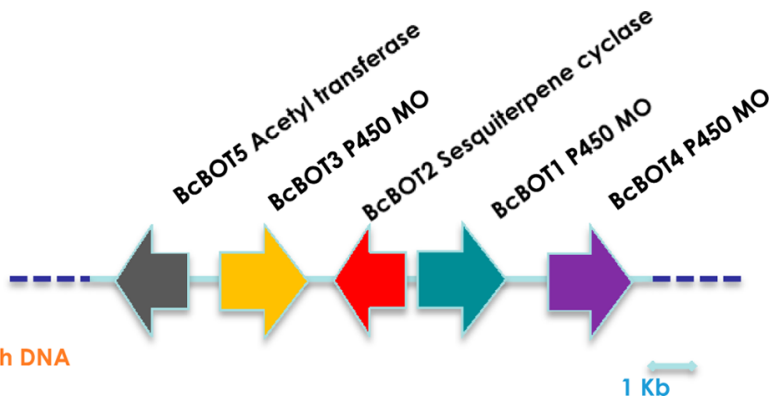

Figure 3. Scheme of the gene cluster involved in the biosynthesis of botrydial. Dashed line indicates AT-rich DNA (more than $80 \%$ of A and $\mathrm{T}$ content).

BOTrydial) involves one gene coding for a sesquiterpene cyclase (BcBOT2), three monooxygenases (BcBOT1, BcBOT3, and $B c B O T 4)$, and an acetyl transferase (BcBOT5).

Gene deactivation studies, which had been carried out previously, had shown that the BcBOT1 gene, encoding a P450 monooxygenase is responsible for one of the final steps in botrydial biosynthesis, ${ }^{27}$ while $B c B O T 2$ codes for a sesquiterpene cyclase (presilphiperfolan- $8 \beta$-ol (PSP) synthase), ${ }^{28}$ which is an early step in botrydial biosynthesis (Figure 2).
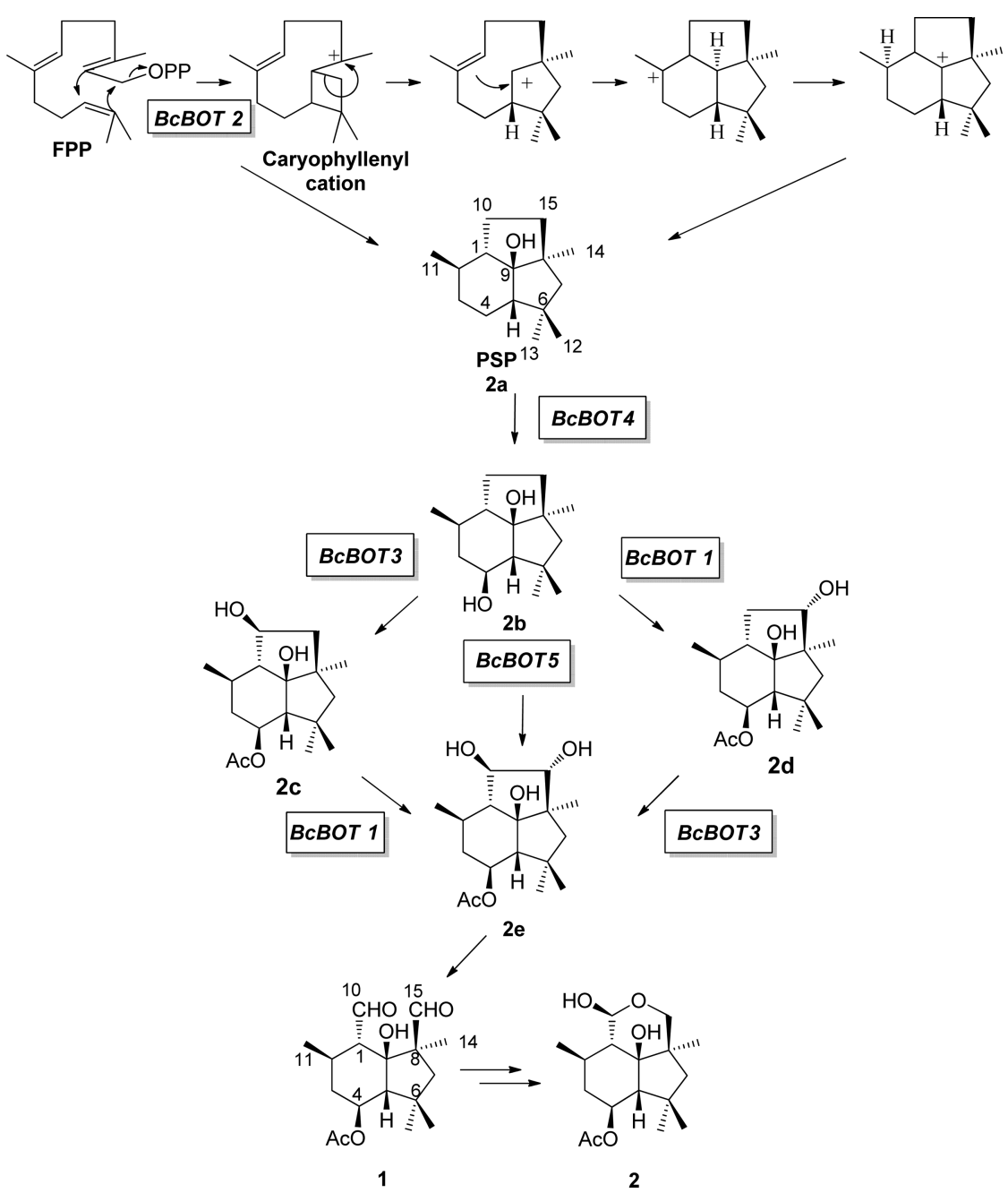

Figure 2. Biosynthetic pathway to botrydial (1). 
The P450 monooxygenases, under mild reaction conditions, catalyze regio- and stereospecific oxidations of nonactivated hydrocarbons, to yield interesting chemical transformations in biosynthetic chemistry. $^{29}$

This paper describes the molecular sequence of botrydial biosynthesis and the functions of the three cytochrome P450 monooxygenases involved in botrydial biosynthesis in terms of the hydroxylations at C-4, C-10, and C-15 on the PSP carbon skeleton. The structures of four new polyketide metabolites, which were isolated from the bcbot $4 \Delta$ mutant, are also reported.

\section{RESULTS AND DISCUSSION}

Previous experiments using isotopically labeled acetate and mevalonate established the origin of the carbon skeleton of botrydial (1) and the occurrence of a backbone rearrangement and 1,3-hydride shift during the cyclization of FPP., 94,30 The original mechanistic proposal (Figure 2) has been corroborated by the incubation of labeled FPP with a recombinant PSP synthase (BcBOT2) to afford the labeled intermediate tricyclic alcohol, presilphiperfolan- $8 \beta$-ol (2a, PSP, probotryane).$^{31}$ This intermediate $\mathbf{2 a}$ is converted to botrydial (1) by the action of the three cytochrome $\mathrm{P} 450$ s encoded by the co-regulated genes $B c B O T 1, B c B O T 3$, and BcBOT4 together with the acetyltransferase (BcBOT5), which function in an as yet unknown sequence.

Deletion of the Genes Encoding BcBOT3 and BcBOT4 Monooxygenases. Previous studies of the amino acid sequences of the $\mathrm{BcBOT} 3$ and $\mathrm{BcBOT} 4$ proteins have revealed the presence of conserved P450 monooxygenase domains, which suggested that they could be involved in botrydial biosynthesis. $^{27,28}$ A gene knockout (KO) approach was used to confirm this hypothesis. Two KO DNA cassettes containing a nourseothricin resistance gene in place of the $B c B O T$ genes, were constructed by PCR fusion and employed to transform protoplasts of the B05.10 wild-type strains (for details, see Methods). The transformation resulted in two independent $b c b o t 3 \Delta$ and two independent $b c b o t 4 \Delta$ mutants. PCR analyses verified integration of the replacement fragment at the targeted loci of the genome and the absence of wild-type nuclei. Both mutants grow and produced conidia similarly to the parent strain B05.10 on a standard rich medium (data not shown).

Chemical Characterization of the bcbot3s and bcbot $4 \Delta$ Mutants. The KO bcbot $3 \Delta$ and bcbot $4 \Delta$ mutants, which had been derived from the B05.10 strain, were grown on a solid malt agar medium. The metabolites were recovered in ethyl acetate and purified by column chromatography on silica gel. The products were finally purified by HPLC to yield the metabolites shown in Figure 4. The results indicated that none of the mutants produced botrydial (1), confirming that these mutations were involved in botrydial biosynthesis.

The chromatographic study, characterization, and quantification of the metabolites biosynthesized by the bcbot $3 \Delta$ mutant showed, in addition to small amounts of botcinin A (6), high levels, $(35 \mathrm{mg} / \mathrm{L})$, of the biosynthetic intermediate $4 \beta$-acetoxy$15 \alpha$-hydroxyprobotryane (2d), Figure 2, which was identified by extensive NMR studies and comparison with authentic samples. In addition, the new metabolite 9 was isolated and characterized.

Compound 9 was obtained as colorless oil. It showed a molecular ion in its HRMS (ESI+) at $\mathrm{m} / z=253.1807$ $\left[\left(\mathrm{C}_{15} \mathrm{H}_{25} \mathrm{O}_{3}\right), \mathrm{M}+\mathrm{H}\right]^{+}$in agreement with the ${ }^{13} \mathrm{C} \mathrm{NMR}$ and DEPT spectra. The ${ }^{1} \mathrm{H}$ and ${ }^{13} \mathrm{C}$ NMR spectra of compound 9

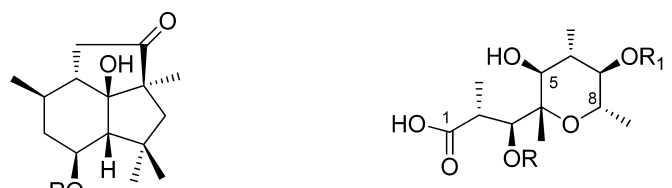

$10 \mathrm{R}=\mathrm{Ac}, \mathrm{n}=3$; 3-acetylbotcinic acid

$9 \mathrm{R}=\mathrm{H}$ 9a $\mathrm{R}=\mathrm{OAC}$ $11 \mathrm{R}=\mathrm{Ac}, \mathrm{n}=5$; 3-aceyilbotcineric acid

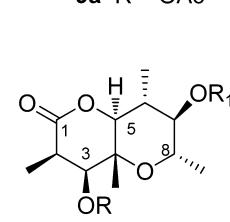

$12 \mathrm{R}=\mathrm{H}, \mathrm{n}=3$; botcinin $\mathrm{E}$ $13 \mathrm{R}=\mathrm{H}, \mathrm{n}=5$; botcinin $\mathrm{G}$

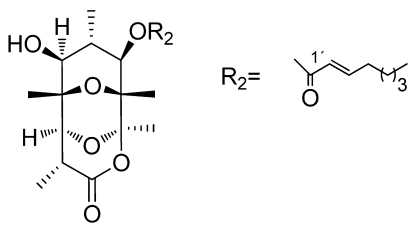

15 5-hydroxy-7-(oct-2(3)-enoyl) botrylactone

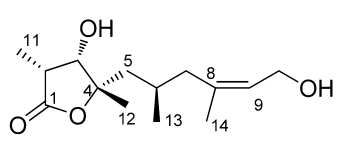

$17 \Delta^{8,9} \mathrm{Z}$ Cinbotolide B

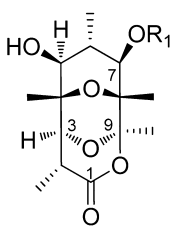

14 5-hydroxy-7-(4-hydroxydec2(3)-enoyl)botrylactone
Figure 4. Some metabolites isolated from mutants $b \operatorname{cbot} 3 \Delta$ and bcbot $4 \Delta$.

contained a similar pattern of signals to the probotryane intermediate (2d). However, the signal for the $\mathrm{C}-4 \mathrm{CH}(\mathrm{OH})$ appeared at $\partial 4.04$, while the signals for the acetate group and the $\mathrm{C}-15 \mathrm{CH}(\mathrm{OH})$ were missing. There was a signal in the ${ }^{13} \mathrm{C}$ NMR spectrum at $\partial 211.0$ characteristic of a cyclopentanone, while the $\mathrm{H}-10$ proton resonances were shifted. These spectroscopic data indicated that compound 9 was the oxidation product of the biosynthetic intermediate $\mathbf{2 d}$ possessing a carbonyl group at C-15. Acetylation of compound 9 yielded a monoacetylated derivative 9a that exhibited the characteristic ${ }^{1} \mathrm{H}$ NMR signals of a methyl group at $\partial 2.03$ and a signal, ddd, at $\partial 5.11$ for the proton geminal to the acetate. The proton and carbon-13 NMR signals of both compounds 9 and 9a were assigned by detailed analysis of their COSY, NOESY, HSQC, and HMBC spectra (Supplementary Table S1). These confirmed their structures and relative stereochemistry.

The fermentation broth of mutant bcbot $4 \Delta$ was chromatographed following the same procedure used for the $\mathrm{KO}$ mutant bcbot $3 \Delta$. Final purification by HPLC and GC-MS yielded the metabolites 2a and 3-8 (Figures 1 and 2) and 10-18 show, in Figure 4. Interestingly, in addition to the key probotryane intermediate $\mathbf{2 a}$, from the cyclization of FPP by the sesquiterpene cyclase $\mathrm{BcBOT} 2$, an overproduction of polyketides was observed yielding the new polyketides 15-18, Figure 4.

The probotryane $\mathbf{2 a}$, which was accumulated by the $b c b o t 4 \Delta$ mutant, was identified in the hexane fraction by comparison with an authentic sample. Although it had not been found in 


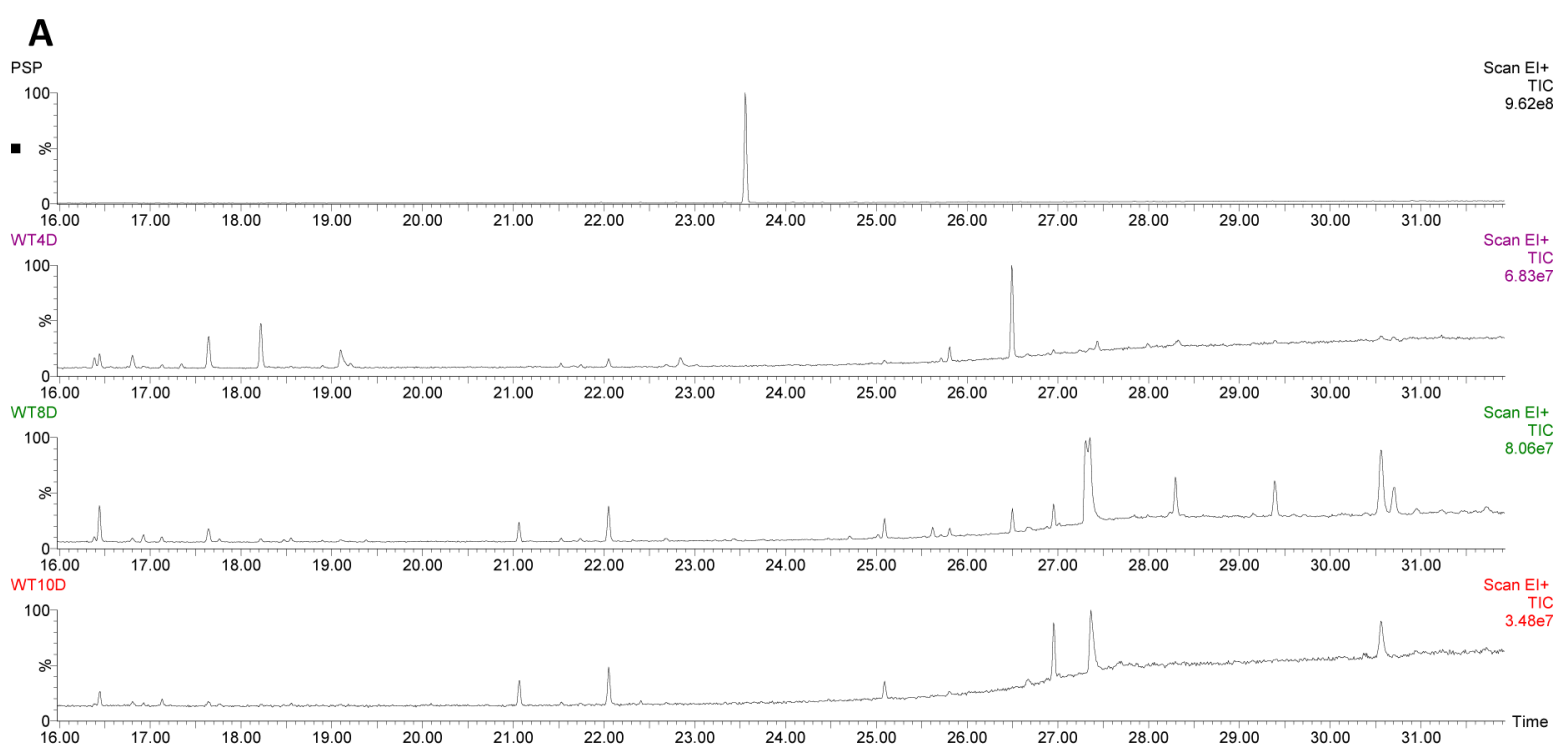

B

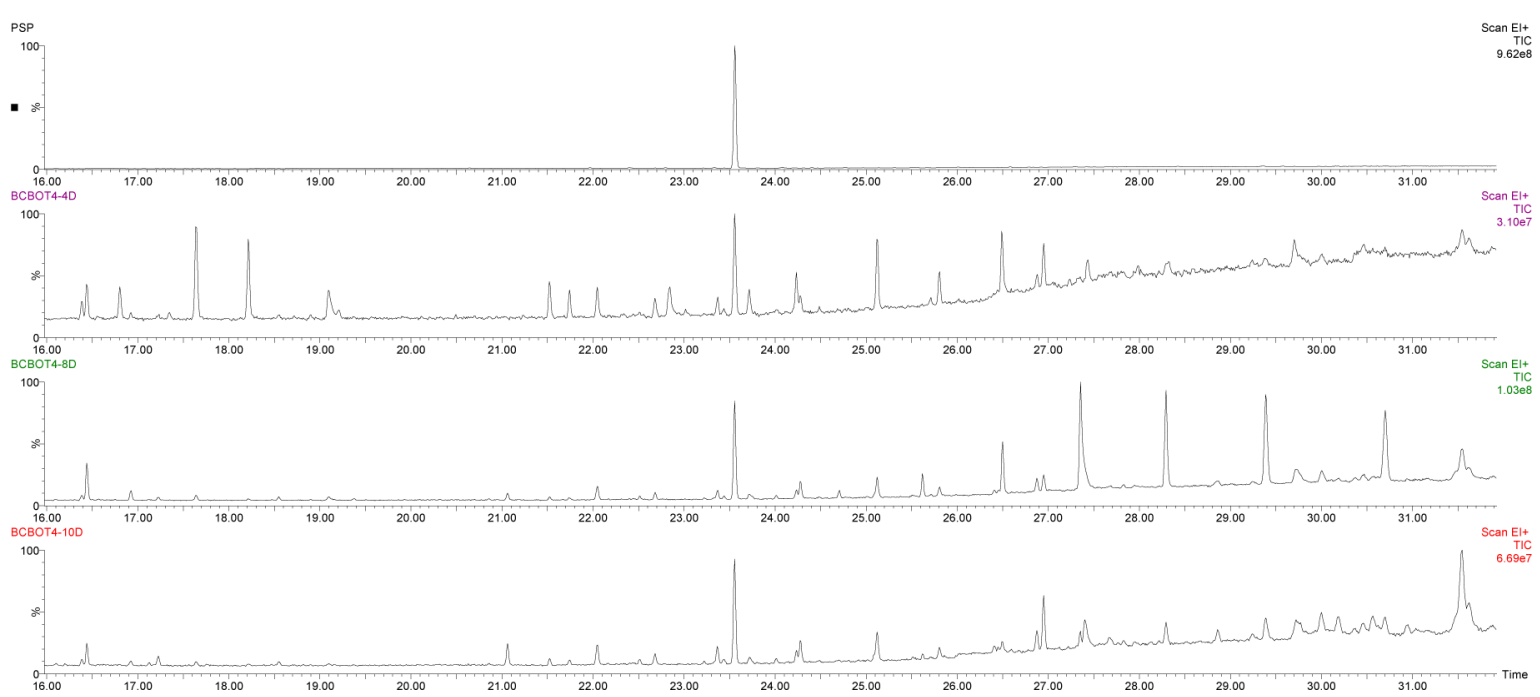

Figure 5. Comparative metabolites profiled by GC-MS analysis, for determination of probotryane 2a in the strain broths. (A) Chromatograms of 2a and of the extract obtained from the wild-type, B05.10 at 4, 8, and 10 days. (B) Chromatograms of $2 \mathrm{a}$ and of the extract obtained from the mutant bcbot $4 \Delta$ at 4,8 , and 10 days.

the wild-type (Figure $5 \mathrm{~A}$ ), it was readily identified in the bcbot $4 \Delta$ mutant fermentation after 4,8 , and 10 days (Figure $5 B)$.

Chemical Characterization of Polyketides Isolated from bcbot4 $\Delta$ Mutant. The metabolites 15 and 16 showed a pattern of NMR signals that were characteristic of the botrylactones. ${ }^{11}$ The ${ }^{13} \mathrm{C}$ NMR contained 22 signals indicating that the side chain contained eight carbon atoms. The ${ }^{1} \mathrm{H}$ NMR of compound 15 resembled that of $\mathbf{1 4}$. The most significant differences were the multiplicity of the signals corresponding to the double bond and the absence of the signal of a geminal proton to a hydroxyl group in the side chain. Thus, the vinylic proton signals appeared as doublet of triplets at $\partial 7.04, \mathrm{H}-3^{\prime}$, and a doublet corresponding to $\mathrm{H}-2^{\prime}, \partial 5.84$, indicating that compound 15 possessed a side chain that was similar to that of compound 14 but with eight carbon atoms and without a hydroxyl group at C-4'.

The HRMS, which was supported by the ${ }^{13} \mathrm{C} N M R$ spectrum, showed that compound $\mathbf{1 5}$ possessed a molecular formula of $\mathrm{C}_{22} \mathrm{H}_{34} \mathrm{O}_{7}$. The COSY, HSQC and HMBC spectra, and NOE experiments (Supplementary Table S2) led to the structure 5-hydroxy-7-(oct-2-enoyl)botrylactone for compound 15.

Compound 16 showed ${ }^{1} \mathrm{H}$ NMR signals that were comparable to botrylactone (3). ${ }^{11}$ The main differences were the lack of the signal typical of the $\mathrm{C}-7 \mathrm{CH}(\mathrm{OH})$ while the signal assigned to the C-6 methyl group was a singlet rather than a doublet. The HRMS and ${ }^{13} \mathrm{C}$ NMR spectra indicated that the compound $\mathbf{1 6}$ had a molecular formula $\mathrm{C}_{14} \mathrm{H}_{22} \mathrm{O}_{5}$. All the carbons and their associated proton signals were assigned from an examination of the COSY, HSQC, HMBC, and NOESY spectra (Table S3), in accord with the structure and relative stereochemistry of compound 16 . The relative stereochemistry of the chiral center at C- 6 followed from the NOE experiments. The rigid structure of the compound meant that a $\beta$ configuration of the C- 6 methyl group would produce NOE interactions with the $\mathrm{C}-4$ and $\mathrm{C}-8$ methyl groups (Supplementary Figure S1), which would not be observed 
with its epimer. However, irradiation of the C-4 methyl group gave NOE interactions with $\mathrm{H}-2$ and $\mathrm{H}-5 \beta$ while irradiation of the C-8 methyl signals revealed interactions with $\mathrm{H}-7 \beta$ and $\mathrm{H}$ 14. Furthermore, irradiation of the C-6 methyl signal only gave NOE interactions with $\mathrm{H}-5 \alpha$ and $\mathrm{H}-7 \alpha$ indicating an $\alpha$ rather than a $\beta$ configuration for this methyl group. These data led to the structure and stereochemistry of $6-\beta$-hydroxy-7-deoxybotrylactone for 16 (Table S3, Figure S1).

The ${ }^{1} \mathrm{H}$ NMR signals of compound $\mathbf{1 7}$ resembled those of cinbotolide A (8). ${ }^{13}$ There was one primary and one secondary hydroxyl group and one double bond in its structure. The main differences were the multiplicities of the $-\mathrm{CH}_{2} \mathrm{OH}$ signal and the $\mathrm{C}-9$ vinylic proton resonance. In addition to the signals assigned to the methyl groups at C-2, C-4, C-6, and C-8, there was a double-doublet at $\partial 5.39(\mathrm{H}-9)$ and signals at $\partial 4.15(\mathrm{dd}$, $J=12.0,6.9 \mathrm{~Hz})$ and $4.05(\mathrm{~d}, J=5.4 \mathrm{~Hz})$ attributed to $\mathrm{H}-10$ and $\mathrm{H}-3$, respectively.

The HRMS together with the ${ }^{13} \mathrm{C}$ NMR spectrum was consistent with a molecular formula $\mathrm{C}_{14} \mathrm{H}_{24} \mathrm{O}_{4}$. Examination of the HSQC, HMBC, and COSY spectra enabled all the carbons and their associated ${ }^{1} \mathrm{H}$ NMR signals to be assigned (Table S4). Thus, compound 17 , which was named cinbotolide B, was the "Z" isomer of cinbotolide A (8).

The molecular formula of compound $\mathbf{1 8}$ was shown by HRMS to be $\mathrm{C}_{14} \mathrm{H}_{24} \mathrm{O}_{5}$. The ${ }^{13} \mathrm{C}$ NMR spectrum contained signals corresponding to four methyl, three methylene, and four methine groups, together with three quaternary carbons. The latter included a signal at $\delta 177.3 \mathrm{ppm}$ attributed to a lactone. The four methyl group signals in the ${ }^{1} \mathrm{H}$ NMR spectrum were three doublets $(\delta 0.98,1.14$, and 1.26) and a singlet $(\delta 1.21)$. The pattern of signals was typical of a cinbotolide lactone containing two hydroxyl groups. The proposed structure 18 was consistent with the HSQC, HMBC, and COSY spectra (Table S5). The stereochemistry was deduced from NOE experiments. When $\mathrm{H}-3$ was irradiated, there were enhancements to the signals corresponding to $\mathrm{H}-2, \mathrm{H}-11$, and $\mathrm{H}-5 \beta$, and when $\mathrm{H}-2$ was irradiated there were enhancements to the signals corresponding to $\mathrm{H}-3, \mathrm{H}-11$, and in particular $\mathrm{H}-5 \alpha$. Consequently compound $\mathbf{1 8}$ was a C-2 epimer $(\mathrm{H}-2 \alpha)$ of the cinbotolides A and B (8 and 17). This epimerization at C-2 has been observed in other polyketides biosynthesized by this fungus, ${ }^{11}$ and it was supported by conformational study carried out with molecular mechanics calculation (Figures S1 and S2). When H-6 was irradiated, NOE effects were observed at H-14, $\mathrm{H}-12, \mathrm{H}-5$, and H-7. A NOE effect on $\mathrm{H}-2$ and $\mathrm{H}-5 \beta$ was observed on irradiation of $\mathrm{H}-5 \alpha$, while effects on $\mathrm{H}-12, \mathrm{H}-9, \mathrm{H}-$ 6 , and $\mathrm{H}-10$ were produced by irradiation of $\mathrm{H}-14$. These effects were consistent with the structure and stereochemistry of 18, named cinbotolide $\mathrm{C}$. In this cinbotolide, epimerization has taken place at $\mathrm{C}-2$, and the $\mathrm{C}-4$ methyl group (C-12) has been oxidized and an ether bridge has been formed to C-8.

Genetic and Molecular Basis of Botrydial Biosynthesis. Although the biochemical function of the enzymes $\mathrm{BcBOT} 1$ and BcBOT2 is known, the functional role of the proteins $\mathrm{BcBOT} 3, \mathrm{BcBOT} 4$, and $\mathrm{BcBOT5}$ are still unknown. In order to understand the molecular basis and to complete the biosynthetic pathway to botrydial (1), the KO mutants for the cytochrome P450 monooxygenases BcBOT3 and BcBOT4 encoding genes were constructed, and their secondary metabolism was studied from the chemical point of view to identify the potential biosynthetic intermediates that were produced and to characterize both of the P450 monooxygenases.
Previous studies showed that BcBOT2 protein catalyzes the cyclization of FPP to the sesquiterpene alcohol PSP, $2 \mathbf{a}$, and is required for the production of botryane and probotryane sesquiterpenes, which firmly established that BcBOT2 is responsible for the initial step of the botrydial biosynthesis (1). ${ }^{28,31}$ On the other hand, inactivation of the BcBOT1 gene demonstrated that those mutants were unable to produce $10 \beta, 15 \alpha$-dihydroxyprobotryane (2e), botrydial (1), or some of its relatives. Instead the intermediate $2 c$ was accumulated, indicating that the monooxygenase $\mathrm{BcBOT} 1$ was responsible for the regiospecific hydroxylation at $\mathrm{C}-15$, in intermediate $\mathbf{2 b}$, to give $\mathbf{2} \mathbf{d}$ in botrydial biosynthesis, Figure $2 .^{27}$

In this context, the knock out $b \operatorname{cbot} 3 \Delta$ and $b \operatorname{cbot} 4 \Delta$ mutants were fermented, and their broths were examined to identify the secondary metabolites that were produced. Compounds $\mathbf{2 d}$ and 9 (Figures 2 and 4) were isolated from the broth of the mutant bcbot $3 \Delta$ and characterized. The large amount of the metabolite $2 \mathrm{~d}$ that was isolated clearly indicated that the monooxygenase $\mathrm{BcBOT} 3$ is involved in the regio- and stereospecific $\beta$ hydroxylation at $\mathrm{C}-10$ on the skeleton of intermediate $\mathbf{2 b}$, yielding intermediate $\mathbf{2 c}$, and thus the hydroxylated derivative at $\mathrm{C}-15,2 \mathrm{~d}$, accumulated.

It was observed that the $b c b o t 3 \Delta$ mutant did not produce botrydial (1) and only produces small amounts of botcinin A (6). This result was unexpected, since we had previously established that the suppression or inhibition of the biosynthetic pathway leading to botrydial (1) induced the overproduction of the second family of toxins, botcinic and botcineric acids $(4,5)$ and botcinins $A$ and $B(6,7) .{ }^{32}$ These results seem to suggest that the metabolic system of the fungus behaved as though the production of botrydial (1) was not inhibited, keeping the gene expression and the production of botcinins low. This result leads us to propose that this P450 monooxygenase as a good target for controlling the fungus and its pathogenicity by its inhibition.

The mutant $b$ cbot $4 \Delta$ accumulated the probotryane $2 \mathrm{a}$ in the less polar fractions. This was established by GC-MS using an authentic sample of $\mathbf{2 a}$ as reference, Figure 5. These results showed that the monooxygenase BcBOT4 catalyzes the first regio- and stereospecific hydroxylation of the probotryane skeleton $2 \mathrm{a}$ at $\mathrm{C}-4$.

The previously reported isolation of intermediates $\mathbf{2 b}$ and acetylated derivatives $2 \mathrm{c}$ and $2 \mathrm{~d}^{23}$ led us to propose that the acetyl transferase BcBOT5 brought about the acetylation of the hydroxyl group at C-4 of probotryane $\mathbf{2 b}$.

These results lead us to propose the complete biosynthetic pathway to botrydial (1), Figure 2. Thus, direct and indirect evidence for the cyclization of FPP to the parent tricyclic alcohol $2 \mathrm{a}$, by the sesquiterpene cyclase BcBOT2, has been reported. ${ }^{28,31}$ In addition, the accumulation of intermediate probotryanes $\mathbf{2 a}, \mathbf{2 c}$, and $\mathbf{2 d}$ confirmed the proposed biosynthetic sequence in which the BcBOT4 monooxygenase produced the hydroxylation at C-4 to give intermediate $\mathbf{2 b}$. Acetylation of the hydroxyl at C-4 was carried out by the acetyl transferase BcBOT5, followed by the combined action of the P450 monooxygenases BcBOT3 and BcBOT1, to yield finally the glycol 2e, via the regio- and stereospecific hydroxylations at $\mathrm{C}-10$ and $\mathrm{C}-15$ of the intermediates $2 \mathrm{c}$ and $\mathbf{2 d}$, respectively.

The cleavage of the $\mathrm{C}-10-\mathrm{C}-15$ bond of probotryane skeleton is an intriguing and chemically important reaction, which could be mediated by some of the monooxygenases or by a combination of them. Many P450 monooxygenases carry out the oxidative cleavage of vicinal diols, such as the side chain 
cleavage (scc) enzyme in testosterone biosynthesis that cleaves the 20,22-diol. ${ }^{33}$ Although the mechanism of this cleavage has never been settled in detail, in this case, it is possible that in the formation of $\mathbf{2 e}$, either $\mathrm{BcBOT} 3$ or $\mathrm{BcBOT} 1$ would oxidize either the 10- or the 15-hydroxy group to the hydroperoxide derivative, which would then undergo heterolytic fragmentation to give the dialdehyde botrydial (1).

The products isolated from these mutants shed an interesting light on a possible mechanism for the cleavage of the C-10-C15 bond in botrydial biosynthesis. Earlier studies had shown that this takes place with the formation of botrydial rather than dihydrobotrydial and the use of stereospecifically labeled mevalonates implicated a trans C-10-C-15 glycol. ${ }^{21,22,24}$ The formation of a C-15 ketone (9) when BcBOT3 is knocked-out but $B c B O T 1$ remains suggests that the oxidation of the $\mathrm{C}-15$ alcohol to a ketone can be mediated by this enzyme. Since $\mathrm{BcBOT} 1$ is a monooxygenase rather than a dehydrogenase, the oxidation may occur by the reaction indicated in Figure 6A, where ketone (9) is obtained, via hydroperoxide, from the alcohol intermediate $\mathbf{2 d}$.

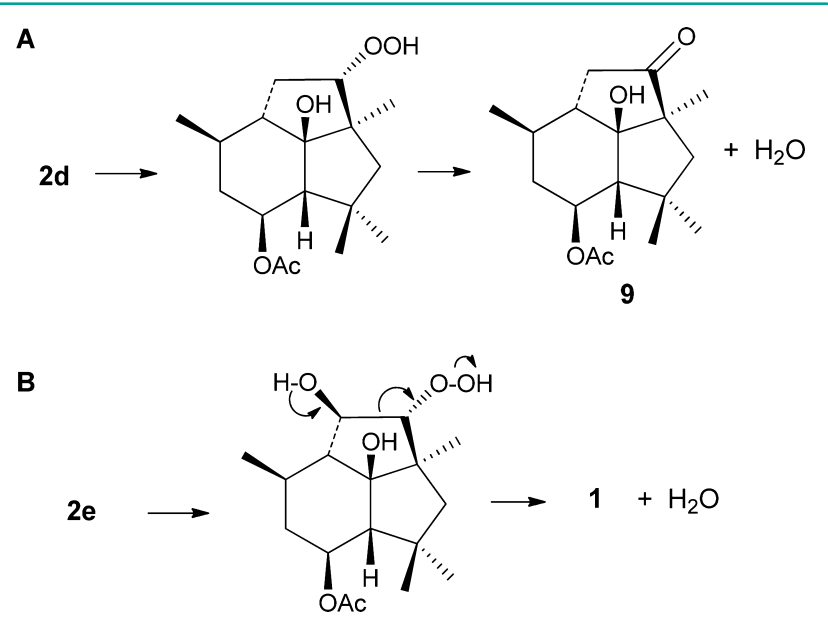

Figure 6. (A) Formation of compound 9 from intermediate 2d. (B) Formation of botrydial (1) from intermediate $2 \mathrm{e}$.

A corollary to this suggestion is that the cleavage of the C$10-\mathrm{C}-15$ bond is also mediated by this enzyme. This would involve the fragmentation of a $\mathrm{C}-15$ hydroperoxide derived from 2e (Figure 6B). This would accord with the labeling pattern from the mevalonates and in particular the trans relationship between the functional groups. ${ }^{24}$

Here we have reported the genetic and molecular basis of botrydial biosynthesis and the assignment of the biochemical function to the five genes that are colocalized in the genome of
$B$. cinerea and constitute the botrydial biosynthesis gene cluster. Genes BcBOT3 and BcBOT4, encoding two cytochrome P450 monooxygenases, catalyzed regio- and stereospecific hydroxylations at the carbons $\mathrm{C}-10$ and $\mathrm{C}-4$, respectively, of the presilphiperfolan- $8 \beta$-ol skeleton. Interestingly, the bcbot $4 \Delta$ mutant overproduced a significant number of polyketides, which included the four new metabolites 15-18.

\section{METHODS}

Fungal Strains. The strain of Botrytis cinerea Pers. Fr. employed in this work, B05.10, was isolated from a Vitis field. ${ }^{34}$

Media and Culture Conditions. B. cinerea strains and mutants were cultivated at $23{ }^{\circ} \mathrm{C}$ with $12 \mathrm{~h}$ daylight per day. Cultures were grown on malt agar medium (MA; $20 \mathrm{~g} / \mathrm{L}$. malt extract, $5 \mathrm{~g} / \mathrm{L}$ yeast extract, $15 \mathrm{~g} / \mathrm{L}$ agar) and minimal medium (MMII; $20 \mathrm{~g} / \mathrm{L}$ glucose, 2 $\mathrm{g} / \mathrm{L} \mathrm{NaNO}_{3}, 1 \mathrm{~g} / \mathrm{L} \mathrm{KH}_{2} \mathrm{PO}_{4}, 500 \mathrm{mg} / \mathrm{L} \mathrm{MgSO}_{4} \cdot 7 \mathrm{H}_{2} \mathrm{O}, 500 \mathrm{mg} / \mathrm{L} \mathrm{KCl}$, $10 \mathrm{mg} / \mathrm{L} \mathrm{FeSO} \cdot 7 \mathrm{H}_{2} \mathrm{O}, 15 \mathrm{~g} / \mathrm{L}$ agar). The transformation medium was a minimal medium supplemented with saccharose (MMV; $20 \mathrm{~g} / \mathrm{L}$ glucose, $200 \mathrm{~g} / \mathrm{L}$ saccharose, $2 \mathrm{~g} / \mathrm{L} \mathrm{NaNO}_{3}, 1 \mathrm{~g} / \mathrm{L} \mathrm{KH}_{2} \mathrm{PO}_{4}, 500 \mathrm{mg} / \mathrm{L}$ $\mathrm{MgSO}_{4} \cdot 7 \mathrm{H}_{2} \mathrm{O}, 500 \mathrm{mg} / \mathrm{L} \mathrm{KCl}, 10 \mathrm{mg} / \mathrm{L} \mathrm{FeSO}{ }_{4} \cdot 7 \mathrm{H}_{2} \mathrm{O}, 15 \mathrm{~g} / \mathrm{L}$ agar). The bcbot 3 and bcbot 4 mutants were selected with nourseothricin fungicide (Werner Bioagent, Germany; $70 \mu \mathrm{g} / \mathrm{mL}$ ).

Standard Molecular Methods: Gene Deletion of the Cytochrome P450-Encoding Genes BCBOT3 and BCBOT4. The B. cinerea genes BcBOT3 and BcBOT4 (GenBank AY277723.2) were deleted by homologous recombination. The $5^{\prime}$ genomic noncoding regions of $B c B O T 3$ and $B c B O T 4$ (882 bp and $1442 \mathrm{bp}$, respectively) were amplified by PCR. In the same way, we obtained the $3^{\prime}$ flanking sequences of BcBOT3 and BcBOT4 (1027 bp and $866 \mathrm{bp}$, respectively) and the nourseothricin resistance gene (nat). For each gene, a knockout (KO) cassette made of the $5^{\prime}$ flanking sequence of bcbot, the nat resistance gene, and the $3^{\prime}$ flanking region of $B c B O T$ was obtained by double-joint PCR fusion ${ }^{35}$ as previously described for B. cinerea. $^{36}$ All the PCR primers are listed in Table 1.

Protoplasts of the B05.10 strain were transformed as previously reported. ${ }^{37}$ Transformants were selected and purified on medium agar containing $70 \mu \mathrm{g} / \mathrm{mL}$ nourseothricin. Gene inactivation was verified by PCR using primers designed outside the $\mathrm{KO}$ cassette and primers designed in the resistance gene nat (primers verif integration, Table 1). In addition, the absence of the BcBOT3 or BcBOT4 WT alleles in the transformant was also checked by PCR. B. cinerea mutants used in this study are described at http://botbioger.versailles.inra.fr/botmut/.

Chemical Methods and Analysis of the bcbot3s and

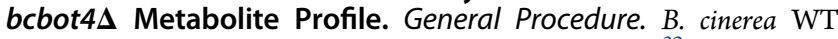
strain and mutants were grown on malt agar medium ${ }^{32}$ at $25^{\circ} \mathrm{C}$ to produce mycelium plugs $(0.8 \mathrm{~cm})$ that were further used to inoculate the medium for metabolite production. All strains were fermented in solid malt agar medium following the reported protocol. ${ }^{32}$ Extraction of the solid agar malt medium was carried out with an ultrasonic bath, using ethyl acetate $(3 \times 0.5 \mathrm{vol})$. The solvents were dried over $\mathrm{Na}_{2} \mathrm{SO}_{4}$ and concentrated to dryness.

Purification of the metabolites was carried out by column chromatography (CC) and semipreparative and analytical HPLC. ${ }^{28,32}$ Optical rotation was recorded with a digital polarimeter.

Table 1. PCR Primers Used for BcBOT3 and BcBOT4 Gene Deletion

\begin{tabular}{|c|c|c|c|}
\hline primer name pair & sequence fwd & sequence rev & usage \\
\hline $\mathrm{BD} 48 / \mathrm{BD} 51$ & tccattaagtctgtttggataaagt & GGGAATGCGGCTCTAGTCGGGTTGCTCTTCTCCAT & $B c B O T 3$ homologuous $5^{\prime}$ region \\
\hline $\mathrm{BD} 49 / \mathrm{BD} 50$ & gggcttgaaaagaatttgtattg & cctgagcggcctgcaaaatggatcgcaacttcgtc & BcBOT3 homologuous $3^{\prime}$ region \\
\hline $\mathrm{BD} 44 / \mathrm{BD} 46$ & gcttcttgtccttccgctac & GGGAATGCGGCTCTAGTTCACTTTCTCCGATTCATG & $B c B O T 4$ homologuous $5^{\prime}$ region \\
\hline $\mathrm{BD} 43 / \mathrm{BD} 45$ & TATGACCGGAGAGCTCGAAA & cctgagcggcctgcacttaaagccctatgacagga & BcBOT4 homologuous $3^{\prime}$ region \\
\hline K7Nat1 Fwd/Rev & TAGAGCCGCATTCCCGATTCGG & TGCAGGCCGCTCAGGGGCAGGG & nourseothricin $\mathrm{K} 7$ \\
\hline $\mathrm{BD} 52 / \mathrm{BD} 12$ & gctacaggcggtggtatctc & CTAAGGGCTCGCGGAGTTG & BcBOT3 purity \\
\hline BD52/Nat1Fverif & gctacaggcggtggtatctc & GACACCGCCCTGTACGAC & $B c B O T 3$ verif integration \\
\hline $\mathrm{BD} 2 / \mathrm{BD} 13$ & cgcgggagaagtctctaagga & gcttgaattcccagggatctg & BcBOT4 purity \\
\hline BD47/Nat1Fverif & TCATTCACTCGAGCATACTTCC & GACACCGCCCTGTACGAC & $B c B O T 4$ verif integration \\
\hline
\end{tabular}


IR spectra were determined on a FT-IR spectrophotometer and reported as wavenumber $\left(\mathrm{cm}^{-1}\right){ }^{13}$

${ }^{1} \mathrm{H}$ and ${ }^{13} \mathrm{C}$ NMR spectra were obtained on Agilent 400 and 500 $\mathrm{MHz}$ spectrometers with $\mathrm{SiMe}_{4}$ as the internal reference at $25{ }^{\circ} \mathrm{C} .{ }^{13}$ Mass spectrometry (MS) and high resolution mass spectrometry (HRMS) were performed on Thermoquest Voyager spectrometer and QTOF mass spectrometer, respectively. ${ }^{13}$

bcbot3 $\Delta$ Metabolite Analysis. Ten days after inoculation, the solid agar malt medium was extracted ${ }^{32}$ yielding a dense oil from $b c b o t 3 \Delta$ culture $(350 \mathrm{mg})$ that was separated by column chromatography on silica gel, eluted with mixtures containing increasing percentages of ethyl acetate/hexane (10-100\%) and methanol as solvent.

Final purification of selected fractions was carried out by HPLC (hexane (Hex)-ethyl acetate (EtAc) 40:60; flow $1 \mathrm{~mL} \mathrm{~min}{ }^{-1}$ ). Three compounds were isolated and characterized: $4 \beta$-acetoxy- $15 \alpha$-hydroxyprobotryane (2d) (39 mg), 4 $\beta$-hydroxyprobotryan-15-ona (9) (1.1 $\mathrm{mg})$, and botcinin A (6) (1.5 mg).

$4 \beta$-Hydroxyprobotryan-15-one (9). Colorless oil; $[\alpha]_{\mathrm{D}}^{25}=-9.62(c$ $\left.=0.106 \mathrm{mg}, \mathrm{CHCl}_{3}\right)$. IR $v_{\max }$ (film) 3425.38, 2961.33, 1729.85, 1454.75, 913.80, $771.28 \mathrm{~cm}^{-1} .{ }^{1} \mathrm{H}$ NMR (600 MHz, $\left.\mathrm{CDCl}_{3}\right), \delta 4.04$ $(1 \mathrm{H}, \mathrm{ddd}, J=11.2,9.6,4.0 \mathrm{~Hz}, \mathrm{H}-4), 2.69(1 \mathrm{H}, \mathrm{dd}, J=18.1,8.6 \mathrm{~Hz}, \mathrm{H}-$ 10), $2.63\left(1 \mathrm{H}, \mathrm{dd}, J=18.1,3.3 \mathrm{~Hz}, \mathrm{H}-10^{\prime}\right), 2.13(1 \mathrm{H}, \mathrm{d}(\mathrm{br}), \mathrm{H}-7)$, $1.91(1 \mathrm{H}$, ddd, J=12.8, 4.0, $2.9 \mathrm{~Hz}, \mathrm{H}-3), 1.82(1 \mathrm{H}, \mathrm{m}, \mathrm{H}-2), 1.64$ $(1 \mathrm{H}$, ddd, $\mathrm{J}=11.6,8.6,3.3 \mathrm{~Hz}, \mathrm{H}-1), 1.46(1 \mathrm{H}, \mathrm{d}, J=9.6 \mathrm{~Hz}, \mathrm{H}-5)$, 1.37 (3H, s, H-14), 1.34 (3H, s, H-13), 1.32 (3H, s, H-12), $0.97(3 \mathrm{H}$, $\mathrm{d}, J=6.4 \mathrm{~Hz}, \mathrm{H}-11) .{ }^{13} \mathrm{C} \mathrm{NMR}\left(151 \mathrm{MHz}, \mathrm{CDCl}_{3}\right) \delta 211.0(\mathrm{~s}, \mathrm{C}-15)$, 94.4 (s, C-9), 70.0 (d, C-4), 63.2 (s, C-8), 60.6 (d, C-5), 48.7 (d, C-1), $47.2(\mathrm{~s}, \mathrm{C}-6), 44.2(\mathrm{t}, \mathrm{C}-7), 44.1(\mathrm{t}, \mathrm{C}-3), 42.6(\mathrm{t}, \mathrm{C}-10), 36.2(\mathrm{q}, \mathrm{C}-$ 12), 33.4 (d, C-2), 27.8 (q, C-13), 23.9 (q, C-14), 21.0 (q, C-11). HRMS $\left(\right.$ ES $\left.^{+}\right) \mathrm{m} / z$ calcd for $\mathrm{C}_{15} \mathrm{H}_{25} \mathrm{O}_{3}[\mathrm{M}+\mathrm{H}]^{+} 253.1804$, found 253.1807.

Acetylation of $4 \beta$-Hydroxyprobotryan-15-one (9). Compound 9 $(5 \mathrm{mg})$ was dissolved in the minimum quantity of dry pyridine $(0.5$ $\mathrm{mL})$, and acetic anhydride $(30 \mathrm{mg})$ was added to the solution at 25 ${ }^{\circ} \mathrm{C}$. The mixture was kept at RT for $24 \mathrm{~h}$, and the solvent was evaporated. The crude was chromatographed over silica gel (hexaneethyl acetate 8:2) and HPLC (Hex-EtAc) 80:20; flow $1 \mathrm{~mL} \mathrm{~min}^{-1}$; $t_{\mathrm{R}}$ $=19.5 \mathrm{~min})$ to give derivative $9 \mathrm{a}(4.5 \mathrm{mg})$.

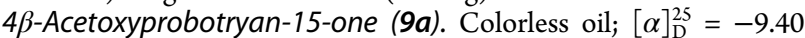
$(c=0.1 \mathrm{mg}, \mathrm{CHCl} 3)$; IR $v_{\max }$ (film) 2350.4, 1727.5, 1248, 776.61, $669.12470 .26 \mathrm{~cm}^{-1} .{ }^{1} \mathrm{H}$ NMR $(600 \mathrm{MHz}$, benzene) $\delta 5.11(1 \mathrm{H}, \mathrm{td}, \mathrm{J}$ $=10.9,4.0 \mathrm{~Hz}), 2.70(1 \mathrm{H}, \mathrm{dd}, \mathrm{J}=18.1,8.6, \mathrm{~Hz}, \mathrm{H}-10), 2.64(1 \mathrm{H}, \mathrm{dd}, \mathrm{J}=$ 18.1, 3.4, Hz, H-10'), 2.17-2.08 (2H, m), 2.03 (3H, s, $\left.\mathrm{CH}_{3} \mathrm{COO}-\right)$, $2.02(1 \mathrm{H}, \mathrm{dt}, \mathrm{J}=7.0,5.4 \mathrm{~Hz}, \mathrm{H}-3), 1.95(1 \mathrm{H}, \mathrm{m}, \mathrm{H}-2), 1.37(3 \mathrm{H}, \mathrm{d}, \mathrm{J}=$ $0.9 \mathrm{~Hz}), 1.29(3 \mathrm{H}, \mathrm{s}), 1.24(2 \mathrm{H}, \mathrm{t}, \mathrm{J}=3.6 \mathrm{~Hz}), 1.16(3 \mathrm{H}, \mathrm{s}), 1.23-1.01$ $(2 \mathrm{H}, \mathrm{m}), 0.95(3 \mathrm{H}, \mathrm{d}, \mathrm{J}=6.4 \mathrm{~Hz}, \mathrm{H}-11) .{ }^{13} \mathrm{C}$ NMR $(151 \mathrm{MHz}$ $\left.\mathrm{CHCl}_{3}\right) \delta 210.5$ (s, C-15), 170.4 (s, $\mathrm{CH}_{3} \mathrm{COO}-$ ), 94.0 (s, C-9), 72.2 (d, C-4), 63.1 (s, C-8), 56.2 (d, C-5), 48.6 (d, C-1), 47.15 (s, C-6), 44.1 (t, C-7), 42.7 (t, C-10), 39.6 (t, C-3), 35.8 (q, C-12), 33.2 (d, C2), 27.5 (q, C-13), 24.1 (q, C-14), $21.4\left(\mathrm{CH}_{3} \mathrm{COO}-\right), 20.9$ (d, C-11). HRMS $\left(\right.$ ES $\left.^{-}\right) \mathrm{m} / z$ calcd for $\mathrm{C}_{17} \mathrm{H}_{25} \mathrm{O}_{4}[\mathrm{M}-\mathrm{H}]^{-}$293.1753, found 293.1779.

bcbot4 4 Metabolite Analysis. The analysis was carried out as described for $b c b o t 3 \Delta$. Evaporation of the solvent under reduced pressure afforded a dense oil from the $b c b o t 4 \Delta$ culture $(360 \mathrm{mg})$ that was chromatographed by CC on silica gel. Final purification by HPLC and GC-MS yielded the metabolite probotryane $\mathbf{2} \mathbf{a}$ and a significant number (15) of metabolites with polyketide skeletons. In addition to the known polyketides the following were isolated and characterized: botrylactone (3,21.7 mg), botcinic and botcineric acids (4 and 5, 6.9 and $4.5 \mathrm{mg})$, botcinins $\mathrm{A}, \mathrm{B}, \mathrm{E}$, and $\mathrm{G}(6,7,12$, and $13,63.6,37.6$, 10.1 , and $7.9 \mathrm{mg})$, cinbotolide $(8,12 \mathrm{mg})$, acetylbotcinic and acetylbotcineric acids (10 and 11, 8.3 and $7.0 \mathrm{mg}$ ), and 5-hydroxy-7(4-hydroxydec-2(3)-enoyl)botrylactone $(\mathbf{1 4}, 12.2 \mathrm{mg}$ ); the new botrylactones, 5-hydroxy-7-(oct-2(3)-enoyl) botrylactone (15, 11.5 mg; semipreparative (Semprep) HPLC, Hex-EtAc-acetone (Act)

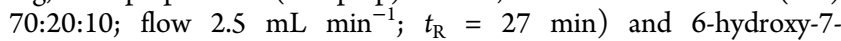
deoxybotrylactone $(16,15 \mathrm{mg}$, semprep HPLC, Hex-EtAc-Act 70:20:10; flow $\left.2.5 \mathrm{~mL} \mathrm{~min}^{-1} ; t_{\mathrm{R}}=38.5 \mathrm{~min}\right)$, and the new cinbotolides B (17, $2.4 \mathrm{mg}$, semprep HPLC, Hex-EtAc-Act 50:40:10; flow $2.5 \mathrm{~mL}$ $\left.\min ^{-1} ; t_{\mathrm{R}}=40 \mathrm{~min}\right)$ and C $(\mathbf{1 8}, 11.8 \mathrm{mg}$, semprep HPLC, Hex-EtAc 75:25; flow $\left.3 \mathrm{~mL} \mathrm{~min}^{-1} ; t_{\mathrm{R}}=45 \mathrm{~min}\right)$.

Presilphiperfolan-8 $\beta$-ol (Probotryane) (2a). The less polar fraction obtained from the bcbot $4 \Delta$ extract with hexane was studied by GCMS. Fermentations, for 4, 8, and 10 days, of wild-type B05.10 and of the mutant bcbot $4 \Delta$ were carried out, and the less polar fractions obtained by extraction with hexane was studied by GC-MS. An authentic sample of the presilphiperfolan- $8 \beta$-ol (2a) was used as reference to detect the compound in the extracts. Compound $2 \mathrm{a}$ was not detected in the hexane fractions from the wild-type at 4,8 , and 10 days. However, the presence of compound $2 \mathrm{a}$ was clearly revealed in all fractions from the fermentations of the mutant $b c b o t 4 \Delta$ on different days (see Figure 5 ).

$2 R, 3 S, 4 S, 6 S, 8 R, 9 R-5$-Hydroxy-7-(oct-2(3)-enoyl) botrylactone (15). Yellow oil; $[\alpha]_{\mathrm{D}}^{25} 4.7\left(c=0.1 \mathrm{mg}, \mathrm{CHCl}_{3}\right)$; IR $v_{\max }$ (film) $3348,2929.48,1721.36,1456.89,1260.51,1105.94,1015.96,719.49$ $\mathrm{cm}^{-1} .{ }^{1} \mathrm{H}$ NMR $\left(400 \mathrm{MHz}, \mathrm{CDCl}_{3}\right) \delta 7.04(1 \mathrm{H}, \mathrm{dt}, J=15.6,6.9 \mathrm{~Hz}$, $\left.\mathrm{H}-3^{\prime}\right), 5.84\left(1 \mathrm{H}, \mathrm{dt}, J=15.6,1.6 \mathrm{~Hz}, \mathrm{H}-2^{\prime}\right), 4.93(1 \mathrm{H}, \mathrm{d}, J=10.9 \mathrm{~Hz}$, H-7), $3.68(1 \mathrm{H}, \mathrm{d}(\mathrm{br}), J=11.1 \mathrm{~Hz}, \mathrm{H}-5), 3.52(1 \mathrm{H}, \mathrm{d}, J=0.5 \mathrm{~Hz}, \mathrm{H}-$ 3), $2.76(1 \mathrm{H}, \mathrm{qd}, J=7.4,0.5 \mathrm{~Hz}, \mathrm{H}-2), 2.21\left(2 \mathrm{H}, \mathrm{m}, \mathrm{H}-4^{\prime}\right), 1.97(1 \mathrm{H}$, $\mathrm{m}, \mathrm{H}-6), 1.55\left(3 \mathrm{H}, \mathrm{s}, \mathrm{C}_{9}-\mathrm{CH}_{3}\right), 1.47\left(3 \mathrm{H}, \mathrm{d}, J=7.4 \mathrm{~Hz}, \mathrm{C}_{2}-\mathrm{CH}_{3}\right)$, $1.38-1.24\left(\mathrm{~m}, \mathrm{H}-5^{\prime}, \mathrm{H}-6^{\prime}, \mathrm{H}-7^{\prime}\right), 1.15\left(3 \mathrm{H}, \mathrm{s}, \mathrm{C}_{4}-\mathrm{CH}_{3}\right), 1.10(3 \mathrm{H}, \mathrm{s}$, $\left.\mathrm{C}_{8}-\mathrm{CH}_{3}\right), 1.04\left(3 \mathrm{H}, \mathrm{d}, J=6.5 \mathrm{~Hz}, \mathrm{C}_{6}-\mathrm{CH}_{3}\right), 0.90(3 \mathrm{H}, \mathrm{t}, J=6.9 \mathrm{~Hz}$, $\left.\mathrm{H}-8^{\prime}\right) .{ }^{13} \mathrm{C}$ NMR $\left(100 \mathrm{MHz}, \mathrm{CDCl}_{3}\right) \delta 171.0(\mathrm{~s}, \mathrm{C}-1), 165.5$ (s, C-1'), 151.4 (d, C-3'), 120.2 (d, C-2'), 104.2(s, C-9), 80.8 (d, C-3), 79.3 (d, C-8), 76.2 (s, C-4), 75.2 (d, C-5), 73.8 (d, C-7), 36.5 (d, C-6), 34.5 (d, C-2), 32.3(t, C-4'), $31.3\left(\mathrm{t}, \mathrm{C}-5^{\prime}\right), 27.6(\mathrm{t}, \mathrm{C}-6), 22.4\left(\mathrm{t}, \mathrm{C}-7^{\prime}\right), 21.7(\mathrm{q}$, $\left.\mathrm{C}_{9}-\mathrm{CH}_{3}\right), 18.5\left(\mathrm{q}, \mathrm{C}_{2}-\mathrm{CH}_{3}\right), 18.2\left(\mathrm{q}, \mathrm{C}_{4}-\mathrm{CH}_{3}\right), 18.1\left(\mathrm{q}, \mathrm{C}_{8}-\mathrm{CH}_{3}\right)$, 13.9 (q, C-8 $\left.8^{\prime}\right), 13.8\left(\mathrm{q}, \mathrm{C}_{6}-\mathrm{CH}_{3}\right)$. HRMS $\left(\mathrm{ES}^{+}\right) \mathrm{m} / z$ calcd for $\mathrm{C}_{22} \mathrm{H}_{35} \mathrm{O}_{7}[\mathrm{M}+\mathrm{H}]^{+}$411.2383, found 411.2370.

6-Hydroxy-7-deoxybotrylactone (16). White amorphous powder; $[\alpha]_{\mathrm{D}}^{25} 1.16\left(c=1.146 \mathrm{mg}, \mathrm{CHCl}_{3}\right)$; IR $v_{\max }($ film $) 3447.87,2938.54$, 1740.30, 1258.90, 1065.66, 976.23, 691.56 cm ${ }^{-1}$; ${ }^{1} \mathrm{H} \mathrm{NMR}$ (500 MHz, $\left.\mathrm{CDCl}_{3}\right) \delta 3.33(1 \mathrm{H}, \mathrm{d}, J=0.7 \mathrm{~Hz}, \mathrm{H}-3), 3.27(1 \mathrm{H}, \mathrm{s}(\mathrm{br}),-\mathrm{OH}), 2.74$ $(1 \mathrm{H}, \mathrm{qd}, J=7.3,0.7 \mathrm{~Hz}, \mathrm{H}-2), 1.91-1.69(4 \mathrm{H}, \mathrm{m}, \mathrm{H}-5, \mathrm{H}-7), 1.44$ $\left(3 \mathrm{H}, \mathrm{d}, J=7.3 \mathrm{~Hz}, \mathrm{C}_{2}-\mathrm{CH}_{3}\right), 1.44\left(3 \mathrm{H}, \mathrm{s}, \mathrm{C}_{9}-\mathrm{CH}_{3}\right), 1.30\left(3 \mathrm{H}, \mathrm{s}, \mathrm{C}_{8}-\right.$ $\left.\mathrm{CH}_{3}\right), 1.27\left(3 \mathrm{H}, \mathrm{s}, \mathrm{C}_{4}-\mathrm{CH}_{3}\right), 1.24\left(3 \mathrm{H}, \mathrm{s}, \mathrm{C}_{6}-\mathrm{CH}_{3}\right) .{ }^{13} \mathrm{C} \mathrm{NMR}(126$ $\left.\mathrm{MHz}, \mathrm{CDCl}_{3}\right) \delta 171.1$ (s, C-1), 104.4 (s, C-9), 81.6 (d, C-3), 76.5 (s,C-8), 72.8 (s, C-4), 70.3 (s, C-6), 45.0 (t, C-5), 43.1 (t,C-7), 34.4 (d, C-2), $28.2\left(\mathrm{q}, \mathrm{C}_{6}-\mathrm{CH}_{3}\right), 27.5\left(\mathrm{q}, \mathrm{C}_{4}-\mathrm{CH}_{3}\right), 26.4\left(\mathrm{q}, \mathrm{C}_{8}-\mathrm{CH}_{3}\right)$, $2206\left(\mathrm{C}_{9}-\mathrm{CH}_{3}\right), 18.6\left(\mathrm{q}, \mathrm{C}_{2}-\mathrm{CH}_{3}\right)$. HRMS $\left(\mathrm{ES}^{-}\right) \mathrm{m} / z$ calcd for $\mathrm{C}_{14} \mathrm{H}_{21} \mathrm{O}_{5}[\mathrm{M}-\mathrm{H}]^{-}$269.1389, found 269.1385.

Cinbotolide $B$ (17). Yellow oil; $[\alpha]_{\mathrm{D}}^{25}-16.03(c=0.131 \mathrm{mg}$, $\mathrm{CHCl}_{3}$ ); IR $v_{\max }$ (film) 3417.83, 2925.61, 1747.89, 1455.50, 1383.58, 1217.32, 996.51, 934.66, 748.70 $\mathrm{cm}^{-1}$; ${ }^{1} \mathrm{H}$ NMR $\left(400 \mathrm{MHz}, \mathrm{CDCl}_{3}\right) \delta$ $5.39(1 \mathrm{H}, \mathrm{q}, J=6.9 \mathrm{~Hz}, \mathrm{H}-9), 4.15(2 \mathrm{H}, \mathrm{dd}, J=12.0,6.9 \mathrm{~Hz}, \mathrm{H}-10)$, $4.05(1 \mathrm{H}, \mathrm{d}, J=5.5 \mathrm{~Hz}, \mathrm{H}-3), 2.94(1 \mathrm{H}, \mathrm{dq}, J=7.3,5.5 \mathrm{~Hz}, \mathrm{H}-2), 2.26$ $(1 \mathrm{H}, \mathrm{dd}(\mathrm{br}), J=13.1,6.4 \mathrm{~Hz}, \mathrm{H}-5), 2.02-1.75\left(3 \mathrm{H}, \mathrm{m}, \mathrm{H}-5^{\prime}, \mathrm{H}-6, \mathrm{H}-\right.$ 7), $1.68\left(3 \mathrm{H}, \mathrm{d}, J=6.9 \mathrm{~Hz}, \mathrm{C}_{8}-\mathrm{CH}_{3}\right), 1.71-1.6\left(1 \mathrm{H}, \mathrm{m}, \mathrm{H}-7^{\prime}\right), 1.36$ $\left(3 \mathrm{H}, \mathrm{s}, \mathrm{C}_{4}-\mathrm{CH}_{3}\right), 1.24\left(3 \mathrm{H}, \mathrm{d}, J=7.3 \mathrm{~Hz}, \mathrm{C}_{2}-\mathrm{CH}_{3}\right), 0.95(3 \mathrm{H}, \mathrm{d}, J=$ $\left.6.2 \mathrm{~Hz}, \mathrm{C}_{6}-\mathrm{CH}_{3}\right) .{ }^{13} \mathrm{C} \mathrm{NMR}\left(100 \mathrm{MHz}, \mathrm{CDCl}_{3}\right) \delta 177.6(\mathrm{~s}, \mathrm{C}-1)$, 137.3 (s, C-8), 125.2 (d, C-9), 87.8 (s, C-4), 76.5 (d, C-3), 60.0 (t, C10), $44.5(\mathrm{t}, \mathrm{C}-7), 40.7(\mathrm{t}, \mathrm{C}-5), 40.0(\mathrm{~d}, \mathrm{C}-2), 27.2(\mathrm{~d}, \mathrm{C}-6), 23.2(\mathrm{q}$, $\left.\mathrm{C}_{4}-\mathrm{CH}_{3}\right), 21.4\left(\mathrm{q}, \mathrm{C}_{6}-\mathrm{CH}_{3}\right), 13.2\left(\mathrm{q}, \mathrm{C}_{8}-\mathrm{CH}_{3}\right), 8.3\left(\mathrm{q}, \mathrm{C}_{2}-\mathrm{CH}_{3}\right)$. HRMS $\left(\right.$ ES $\left.^{+}\right) \mathrm{m} / z$ calcd for $\mathrm{C}_{14} \mathrm{H}_{25} \mathrm{O}_{4}[\mathrm{M}+\mathrm{H}]^{+}$257.1747, found 257.1758 .

Cinbotolide C (18). Colorless oil; $[\alpha]_{\mathrm{D}}^{25} 52.5\left(c=0.12 \mathrm{mg}, \mathrm{CHCl}_{3}\right)$; IR $v_{\max }$ (film) 3426.45, 2926.73, 1752.33, 1643.35, 1456.46, 1046.65, $771.09 \mathrm{~cm}^{-1} .{ }^{1} \mathrm{H}$ NMR $\left(400 \mathrm{MHz}, \mathrm{CDCl}_{3}\right) \delta 4.18(1 \mathrm{H}, \mathrm{d}, J=5.5 \mathrm{~Hz}$, $\mathrm{H}-3), 4.01(2 \mathrm{H}, \mathrm{d}, J=1.3 \mathrm{~Hz}, \mathrm{H}-12), 3.65(1 \mathrm{H}, \mathrm{q}, J=6.5 \mathrm{~Hz}, \mathrm{H}-9)$, $2.86(1 \mathrm{H}, \mathrm{dq}, J=7.3,5.5 \mathrm{~Hz}, \mathrm{H}-2), 2.26(1 \mathrm{H}, \mathrm{m}, \mathrm{H}-6), 1.78(1 \mathrm{H}$, ddd, $J=14.5,2.8,1.6 \mathrm{~Hz}, \mathrm{H}-5), 1.66\left(1 \mathrm{H}, \mathrm{dd}, J=14.2,11.4 \mathrm{~Hz}, \mathrm{H}-7^{\prime}\right), 1.57$ $\left(1 \mathrm{H}, \mathrm{dd}, J=14.5,10.9 \mathrm{~Hz}, \mathrm{H}-5^{\prime}\right), 1.47(1 \mathrm{H}, \mathrm{dt}, J=14.2,1.7 \mathrm{~Hz}, \mathrm{H}-7)$, $1.26\left(3 \mathrm{H}, \mathrm{d}, J=7.3 \mathrm{~Hz}, \mathrm{C}_{2}-\mathrm{CH}_{3}\right), 1.21\left(3 \mathrm{H}, \mathrm{s}, \mathrm{C}_{8}-\mathrm{CH}_{3}\right), 1.14(3 \mathrm{H}, \mathrm{d}$, $\left.J=6.5 \mathrm{~Hz}, \mathrm{C}_{9}-\mathrm{CH}_{3}\right), 0.98\left(3 \mathrm{H}, \mathrm{d}, J=6.7 \mathrm{~Hz}, \mathrm{C}_{6}-\mathrm{CH}_{3}\right) .{ }^{13} \mathrm{C} \mathrm{NMR}$

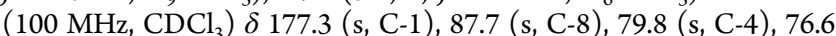
(d, C-3), 74.4 (d, C-9), 63.1 (t, C-12), 45.7 (t, C-5), 42.7(t, C-7), 39.7 (d, C-2), 24.6 (q, $\left.\mathrm{C}_{6}-\mathrm{CH}_{3}\right), 24.6(\mathrm{~d}, \mathrm{C}-6), 18.9\left(\mathrm{q}, \mathrm{C}_{8}-\mathrm{CH}_{3}\right), 17.3$ (q, $\left.\mathrm{C}_{10}-\mathrm{CH}_{3}\right), 8.3\left(\mathrm{q}, \mathrm{C}_{2}-\mathrm{CH}_{3}\right)$. HRMS $\left(\mathrm{ES}^{+}\right) \mathrm{m} / z$ calcd for $\mathrm{C}_{14} \mathrm{H}_{25} \mathrm{O}_{5}$ $[\mathrm{M}+\mathrm{H}]^{+}$273.1702, found 273.1701. 


\section{ASSOCIATED CONTENT}

\section{S Supporting Information}

This material is available free of charge via Internet. The Supporting Information is available free of charge on the ACS Publications website at DOI: 10.1021/acschembio.6b00581.

Details of spectroscopic and characterization data, and reproductions of ${ }^{1} \mathrm{H}$ - and ${ }^{13} \mathrm{C}$ NMR spectra (PDF)

\section{AUTHOR INFORMATION}

\section{Corresponding Author}

*E-mail: isidro.gonzalez@uca.es.

\section{Notes}

The authors declare no competing financial interest.

\section{ACKNOWLEDGMENTS}

This research was supported by a grant from Ministerio de Economía y Competitividad (AGL2015-65684-C2-1-R) (MINECO-FEDER). Use of NMR facilities at the Servicio Centralizado de Ciencia y Tecnologia (SCCYT) of the University of Cádiz is acknowledged. We thank D. Cane for the generous gift of a sample of compound $2 \mathrm{a}$.

\section{REFERENCES}

(1) Hanson, J. R. (2008) The Chemistry of Fungi, RSC Publishing, Cambridge, U.K.

(2) Walton, J. D. (2000) Horizontal gene transfer and the evolution of secondary metabolite gene clusters in fungi: An hypothesis. Fungal Genet. Biol. 30, 167-171.

(3) Khaldi, N., Collemare, J., Lebrun, M. H., and Wolfe, K. H. (2008) Evidence for horizontal transfer of a secondary metabolite gene cluster between fungi. Genome Biol. 9, R18.

(4) Schumacher, J., Gautier, A., Morgant, G., Studt, L., Ducrot, P. H., Le Pêcheur, P., Azeddine, S., Fillinger, S., Leroux, P., Tudzynski, B., and Viaud, M. (2013) A functional bikaverin biosynthesis gene cluster in rare strains of Botrytis cinerea is positively controlled by VELVET. PLoS One 8 (1), e53729.

(5) Bok, J. W., Chiang, Y.-M., Szewczyk, E., Reyes-Domingez, Y., Davidson, A. D., Sanchez, J. F., Lo, H.-C., Watanabe, K., Strauss, J., Oakley, B. R., Wang, C. C. C., and Keller, N. P. (2009) Chromatinlevel regulation of biosynthetic gene clusters. Nat. Chem. Biol. 5, 462464.

(6) Palmer, J. M., and Keller, N. P. (2010) Secondary metabolism in fungi: Does chromosomal location matter? Curr. Opin. Microbiol. 13, 431-436.

(7) Choquer, M., Fournier, E., Kunz, C., Levis, C., Pradier, J. M., Simon, A., and Viaud, M. (2007) FEMS Microbiol. Lett. 277, 1-10.

(8) Williamson, B., Tudzynski, B., Tudzynski, P., and Van Kan, J. A. L. (2007) Mol. Plant Pathol. 8, 561-580.

(9) Collado, I. G., Sánchez, A. J. M., and Hanson, J. R. (2007) Fungal terpene metabolites: Biosynthetic relationships and the control of the phytopathogenic fungus Botrytis cinerea. Nat. Prod. Rep. 24, 674-686. (10) Moraga, J., Pinedo, C., Duran-Patron, R., Collado, I. G., and Hernandez-Galán, R. (2011) Botrylactone: new interest in an old molecule, review of its absolute configuration and related compounds. Tetrahedron 67, 417-420.

(11) Shiina, I., and Fukui, H. (2009) Chemistry and structural determination of botcinolides, botcinins, and botcinic acids. Chem. Commun. 4, 385-400.

(12) Massaroli, M., Moraga, J., Bastos Borges, K., Ramírez-Fernández, J., Viaud, M., González Collado, I., Durán-Patrón, R., and HernándezGalán, R. (2013) A shared biosynthetic pathway for botcinins and botrylactones revealed through gene deletions. ChemBioChem 14, $132-136$.

(13) Botubol, J. M., Duran-Peña, M. J., Macías-Sánchez, A. J., Hanson, J. R., Collado, I. G., and Hernández-Galán, R. (2014) The
Asymmetric Total Synthesis of Cinbotolide. A Revision of the Original Structure. J. Org. Chem. 79, 11349-11358.

(14) Rebordinos, L., Cantoral, J. M., Prieto, M. V., Hanson, J. R., and Collado, I. G. (1996) The phytotoxic activity of some metabolites of Botrytis cinerea. Phytochemistry 42, 383-387.

(15) Colmenares, A. J., Aleu, J., Durán-Patrón, R., Collado, I. G., and Hernández-Galán, R. (2002) The putative role of botrydial and related metabolites in the infection mechanism of Botrytis cinerea. J. Chem. Ecol. 28, 997-1005.

(16) Deighton, N., Muckenschnabel, I., Colmenares, A. J., Collado, I. G., and Williamson, B. (2001) Botrydial is produced in plant tissues infected by Botrytis cinerea. Phytochemistry 57, 689-692.

(17) Rossi, F. R., Gárriz, A., Marina, M., Romero, F. M., Gonzalez, M. E., Collado, I. G., and Pieckenstain, F. L. (2011) The sesquiterpene botrydial produced by Botrytis cinerea induces the hypersensitive response on plant tissues and its action is modulated by salicylic acid and jasmonic acid signaling. Mol. Plant-Microbe Interact. 24 (8), 88896.

(18) Fehlhaber, H. W., Geipel, R., Mercker, H. J., Tschesche, R., Welmar, K., and Schönbeck, F. (1974) Botrydial, ein SesquiterpenAntibiotikum aus der Nahrlosung des Pilzes Botrytis cinerea. Chem. Ber. $107,1720-1730$.

(19) Lindner, H. J., and von Gross, B. (1974) Die Kristall- und Molekulstruktur yon Dihydrobotrydial. Chem. Ber. 107, 3332-3336.

(20) Wolf, H. (1966) $\delta$-Lactones. Cotton effect and conformation of the $\delta$-lactone ring. Tetrahedron Lett. 7, 5151-5156.

(21) Bradshaw, A. P. W., Hanson, J. R., and Nyfeler, R. (1981) Studies in terpenoid biosynthesis. Part 24. The formation of the carbon skeleton of the sesquiterpenoid dihydrobotrydial. J. Chem. Soc., Perkin Trans. 1 1, 1469-1472.

(22) Bradshaw, A. P. W., Hanson, J. R., Nyfeler, R, and Sadler, I. H. (1982) Studies in terpenoid biosynthesis. Part 25. The fate of the mevalonoid hydrogen atoms in the biosynthesis of the sesquiterpenoid, dihydrobotrydial. J. Chem. Soc., Perkin Trans. 1 1, 2187-2192.

(23) Durán-Patrón, R., Colmenares, A. J., Hernández-Galán, R., and Collado, I. G. (2001) Some keymetabolic intermediates in the biosynthesis of botrydial and related compounds. Tetrahedron 57, 1929-1933.

(24) Hanson, J. R. (1981) The biosynthesis of some sesquiterpenoids. Pure Appl. Chem. 53, 1155-1162.

(25) Fillinger, S., Amselem, J., Artiguenave, F., Billaut, A., Choquer, M., Couloux, A., Cuomo, C., Dickman, M. B., Fournier, E., Gioti, A., Giraud, C., and Kodira, C. (2007) The genome projects of the plant pathogenic fungi Botrytis cinerea and Sclerotinia sclerotiorum. Macromol. Grape Wines, 125-133.

(26) Amselem, J., Cuomo, C. A., van Kan, J. A., et al. (2011) Genomic analysis of the necrotrophic fungal pathogens Sclerotinia sclerotiorum and Botrytis cinerea. PLoS Genet. 7, e1002230.

(27) Siewers, V., Viaud, M., Jimenez-Teja, D., Collado, I. G., Gronover, C. S., Pradier, J.-M.-M., Tudzynski, B., and Tudzynski, P. (2005) Functional analysis of the cytochrome P450 monooxygenase gene bcbot1 of Botrytis cinerea indicates that botrydial is a strainspecific virulence factor. Mol. Plant-Microbe Interact. 18, 602-612.

(28) Pinedo, C., Wang, C.-M., Pradier, J.-M., Dalmais, B., Choquer, M., Le Pêcheur, P., Morgant, G., Collado, I. G., Cane, D. E., and Viaud, M. (2008) Sesquiterpene synthase from the botrydial biosynthetic gene cluster of the phytopathogen Botrytis cinerea. ACS Chem. Biol. 3, 791-801.

(29) Urlacher, V. B., and Girhard, M. (2012) Cytochrome P450 monooxygenases: an update on perspectives for synthetic application. Trends Biotechnol. 30, 26-36.

(30) Wang, S. C., and Tantillo, D. J. (2008) Prediction of a New Pathway to Presilphiperfolanol. Org. Lett. 10, 4827-4830.

(31) Wang, C.-M., Hopson, R., Lin, X., and Cane, D. E. (2009) Biosynthesis of the Sesquiterpene Botrydial in Botrytis cinerea. Mechanism and Stereochemistry of the Enzymatic Formation of Presilphiperfolan-8 $\beta$-ol. J. Am. Chem. Soc. 131, 8360-8361.

(32) Dalmais, B., Schumacher, J., Moraga, J., LE Pêcheur, P., Tudzynski, B., Collado, I. G., and Viaud, M. (2011) The Botrytis 
cinerea phytotoxin botcinic acid requires two polyketide synthases for production and has a redundant role in virulence with botrydial. Mol. Plant Pathol. 12, 564-79.

(33) Luttrell, B., Hochberg, R. B., Dixon, W. R., Mcdonald, P. D., and Lieberman, S. (1972) Studies on the biosynthetic conversion of cholesterol into pregnenolone. Side chain cleavage of a $t$-butyl analog of $20 \alpha$-hydroxycholesterol, (20R)-20-t-butyl-5-pregnene-3 $\beta$, 20-diol, a compound completely substituted at C-22. J. Biol. Chem. 247 (5), $1462-1472$.

(34) Quidde, T., Osbourn, A. E., and Tudzynski, P. (1998) Detoxification of $\alpha$-tomatine by Botrytis cinerea. Physiol. Physiol. Mol. Plant Pathol. 52, 151-165.

(35) Yu, J. H., Hamari, Z., Han, K. H., Seo, J. A., Reyes-Domínguez, Y., and Scazzocchio, C. (2004) Double-joint PCR: a PCR-based molecular tool for gene manipulations in filamentous fungi. Fungal Genet. Biol. 41 (11), 973-81.

(36) Antal, Z., Rascle, C., Cimerman, A., Viaud, M., Billon-Grand, G., Choquer, M., and Bruel, C. (2012) The homeobox BcHOX8 gene in Botrytis cinerea regulates vegetative growth and morphology. PLoS One 7 (10), e48134.

(37) Simon, A., Dalmais, B., Morgant, G., and Viaud, M. (2013) Screening of a Botrytis cinerea one-hybrid library reveals a Cys2His2 transcription factor involved in the regulation of secondary metabolism gene clusters. Fungal Genet. Biol. 52, 9-19. 